\title{
Assessment of Climate Technology Demands in Chinese Sponge City
}

\author{
Zhanyun Ma', Jing Hu${ }^{1,2}$, Peng Feng ${ }^{3}$, Qingxian $\mathrm{Gao}^{1 *}$, Sijia Qu ${ }^{4}$, Wei Song5, Jinghao Liu ${ }^{5}$ \\ ${ }^{1}$ Chinese Research Academy of Environmental Sciences, Beijing, China \\ ${ }^{2}$ Capital Normal University, Beijing, China \\ ${ }^{3}$ China Center for Resource Satellite Data and Applications, Beijing, China \\ ${ }^{4}$ Chongqing Jiatong University, Chongqing, China \\ ${ }^{5}$ China Urban Construction Design \& Research Institute Co., Ltd., Beijing, China \\ Email: *gaoqx@craes.org.cn
}

How to cite this paper: Ma, Z.Y., Hu, J., Feng, P., Gao, Q.X., Qu, S.J., Song, W. and Liu, J.H. (2017) Assessment of Climate Technology Demands in Chinese Sponge City. Journal of Geoscience and Environment Protection, 5, 102-116.

https://doi.org/10.4236/gep.2017.512008

Received: October 11, 2017

Accepted: December 22, 2017

Published: December 25, 2017

Copyright (C) 2017 by authors and Scientific Research Publishing Inc. This work is licensed under the Creative Commons Attribution International License (CC BY 4.0).

http://creativecommons.org/licenses/by/4.0/

\begin{abstract}
Sponge city is a development pattern used to realize natural accumulation, natural infiltration and natural purification of rainwater through urban planning and construction management. Sponge city technology is widely used as the critical approaches in natural rainwater management and it is one of the best techniques to adapt climate change events in modern cities. In the paper, we firstly reviewed background information of sponge city construction and the development, key technologies, and economic benefit analysis of stormwater management in foreign countries. Then, we analyzed the technology gap between China and developed countries in two aspects (planning design method and Low Impact Development (LID) project design). Then, we pointed out the main obstacles in sponge city technology transfer and proposed to improve the basic data sharing system and strengthen the economic return system. On the basis of sponge city planning theory and sponge city technologies, taking Shenzhen as an example, we analyzed the ideas and plans of sponge city construction in rainy areas and completed the assessment of current climate technology demands in Chinese sponge city. The study provides the basis for the improvements in sponge city construction and adaptation to climate change.
\end{abstract}

\section{Keywords}

Adaptation to Climate Change, Sponge City Construction, Sponge City Planning and Technology, Stormwater Management

\section{Introduction}

Due to global climate change, storms and other extreme climate events occur 
frequently. The rapid development of urban construction and the increasing area of impermeable pavement have changed the conditions of the underlying surface. Carbon emission and particular matters result in urban heat island effect, which further leads to frequent intense rainstorm. Due to the deteriorated urban ecological environment, the problems of water logging, water pollution, and discomfort caused by air humidity change have been exacerbated.

As the hub of human activities and economic activities, cities are affected by climatic change easily. Climate change may increase the frequency of natural disasters. Adaptation of cities to climatic change has become one of key points of tackling climatic change at present. The Ministry of Housing and Urban-Rural Development of the State Development and Reform Committee of China issued the Action Plan for Urban Adaptation to Climate Change [1] in Feb. 2016. The plan aims to build climate-adapted cities by comprehensively increasing cities' capacity of adapting to climatic change. City adaptation refers to establish a series of policies and investment plans to solve the vulnerability problem of cities under the influence of climate change. The sponge city theory proposed based on the hydrological characteristics and water source conditions in China can maximize the overall benefits of sustainable development and improve the ability to adapt to climate change. Sponge city planning and technology are helpful to improve urban waterlogging control, runoff pollution control and water resource utilization.

Sponge city refers to a development pattern used to realize natural accumulation, natural infiltration and natural purification through urban planning, construction management, and adsorption infiltration effect of rainwater [2]. The technical route of sponge city is composed of source reduction, process management, and end control and the key measures include permeation, retention, accumulation, purification, usage, drainage, etc. These measures aim to reduce negative impact of city construction on natural ecology through rainwater management and improve water environment, water safety, and water resource conditions.

The core of sponge city construction is the implementation of the modern stormwater management system [3]. The United States, Australia, Britain and other developed countries began to explore the application of rainwater system model for low impact development in the end of the twentieth century. Overall, developed countries urban stormwater management concept and system also experienced the transformation process from tube drainage, waterlogging prevention, and water quality control, to multi-objective control in order to restore natural hydrological cycle [4]. In the early 21 st century, China put forward the idea of building sponge city with Chinese characteristics, started to study the waterlogging problem in Chinese cities. In the developed urban areas some exploration efforts were first made. For example, in Guangming New District in Shenzhen, a residential area in Beijing Shunyi District, and the Shanghai World Expo District, rainwater system construction projects with low impact were es- 
tablished [5]. In 2014, the Ministry of Housing and Urban-Rural Development issued The Sponge Urban Construction Technology Guide to Rainwater System Construction for Low Impact Development (Trial) [6]. The guide gives the systematical contents of rainwater systems, including targets, indicators, process, means and management for sponge city construction. In 2015, 16 cities, such as Jiaxing, Xiamen, Ji'nan, Wuhan, Nanning, and Chongqing, were selected as the pilot cities for sponge city construction.

Combined with the practices in foreign rainwater management, in this paper, we discussed the necessity and feasibility of the construction of sponge city in two aspects of key technologies and benefit analysis, pointed out the problems in Chinese sponge city to adapt to climate change, including technology demands, technology gap, and technology transfer barriers, and made the case analysis with Shenzhen City as an example of sponge city construction. In this paper, we made a comprehensive evaluation of China's sponge city construction and implementation and provided the basis for sponge city construction to adapt to climate change.

\section{Connotations and Methods of the Climate Technology Demand Assessment of Chinese Sponge City}

\subsection{Connotation of the Climate Technology Demand Assessment of Chinese Sponge City}

Climate adaptation technology demand assessment involves domestic and foreign demands. The assessment can provide the insight into the development status of adaptation technology of various subsectors as well as the potential and capital investment of adaptation technology and help us to identify the more important adaptation subsectors and more valuable adaptation technologies for the synergetic development of various subsectors, including construction, infrastructure maintenance, land use and management and ecological service systems. City adaptation actions can not only slow climate change but also ensure the sustainable development. Adaptation technology demand assessment can lay the foundation for urban planning. Adaptation actions provide the basis and guidance to build urban resilience and realize the sustainable development. There are more chances in the developing cities which are still in the infrastructure construction stage. Moreover, through the analysis of the gap adaptation technologies between China and foreign countries, adaptation technology demand assessment can promote the adaptation technology transfer and is meaningful for addressing climate change and enhancing the city's adaptation ability.

\subsection{Methods of the Climate Technology Demand Assessment of Chinese Sponge City}

The methodology of technology demand assessment depends on available data and information. If a technology has sufficient quantitative data and informa- 
tion, a formal decision analysis can be used to prioritize the technology options. The more qualitative case studies can be applied to identify the technologies with limited information or with attributes that cannot be quantified reliably. In this study, technologies are identified and demands are evaluated by combining the decision analysis method with the qualitative case research method.

The first stage is to discuss and determine appropriate criteria and indicators for prioritizing technologies. An appropriate set of criteria can reflect the contribution of a technology to the environmental, social, economic and technological development priorities defined previously. Even though the direct impact of a technology may be observed quickly from changes in environmental indicators, the adaptation process should promote the overall social and economic welfare as well as potential technological advances.

The second stage is to assign the weights of these criteria determined by stakeholders. The weights can be obtained through interviews with stakeholders. The methodology to derive the weights is similar to the one that is used to prioritize subsectors. Once the criteria and corresponding weights are determined, a final assessment decision can be made through an appropriate assessment method. Assessment methodologies include Multi-Criteria Decision Analysis (MCDA) [7] and economic decision rule. MCDA evaluates and ranks technologies using a decision matrix to integrate valuations, risks, and uncertainties. Cost-Benefit Analysis is a useful economic tool to prioritize technologies, which is a systematic approach that calculates and compares benefits and costs of a project. Both methods require the sensitivity analysis to adjust risks and uncertainties. These methods are summarized below.

\section{Foreign Practices in Stormwater Management}

Foreign stormwater management started early and became relatively mature during the urban infrastructure construction. Prince George, Maryland, the United States [8], proposed the concept of LID in the 1980s, in which small-scale water treatment facilities were used to replace traditional drainage pipeline in order to reduce the runoff pollution caused by rainwater. The concept was introduced to Australia [9] in 1990s, which evolved to form WSUD. The core concept of WSUD is to reduce the hydrological impact on the surrounding environment and its key elements include urban flood control, water quality improvement, and stormwater collection. Its principle is to reduce the cost of drainage water pipeline and wastewater management facility with a combination of stormwater utilization and landscape to reduce the runoff and peak flow of rainwater. UK [10] and New Zealand [11] adopted the similar concept for urban stormwater management guidance, such as MNPs and SUDs. Generally speaking, stormwater management in developed counties had gradually developed from single target (quantity control and quality control) to the whole process control. The change tendency is shown in Figure 1 and Figure 2.

Based on the practices of developed countries, the definition of sponge city in China includes almost all the domestic and international aspects: water quantity, 


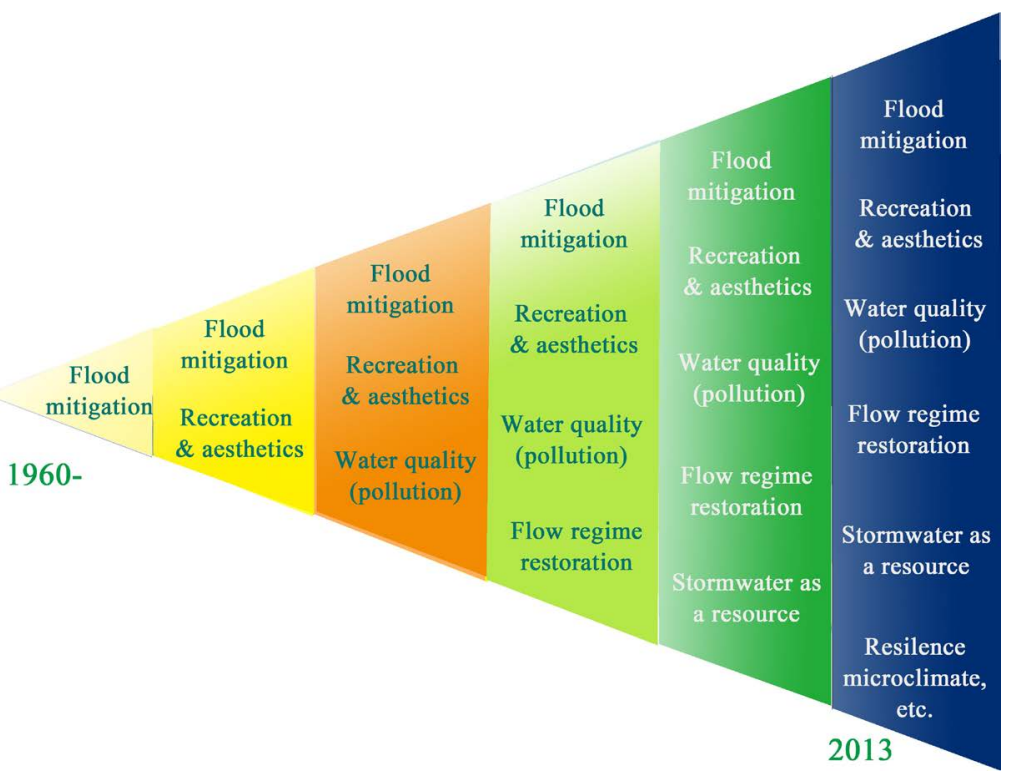

Figure 1. Connotation changes of stromwater management in developed countries.

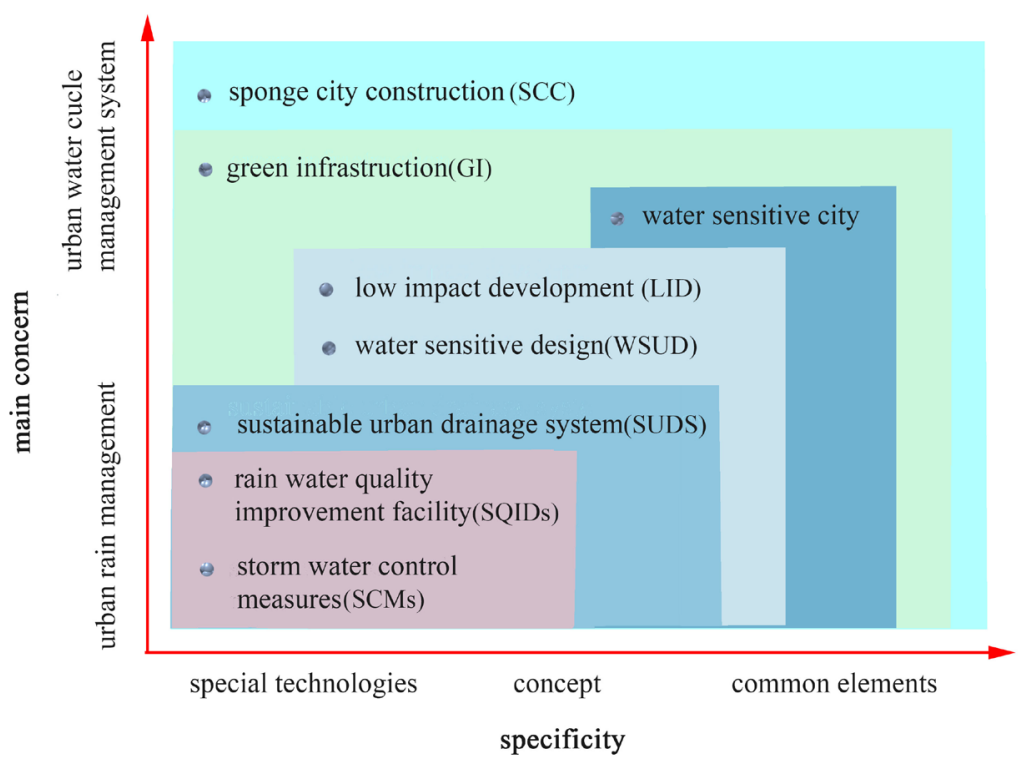

Figure 2. Terminology extension of stormwater management.

water quality, whole management process, etc. Therefore, the source reduction measure is similar to the measure in LID. The process control measure includes idea from both LID and SUDs. The end control equals to large drainage system and water quality improvement facilities, such as drainage system establishment and water system protection.

\section{Key Technologies and Economic Benefit Analysis of Sponge City Construction}

\subsection{Key Technologies of Sponge City Construction}

Key technologies of sponge city construction involves urban planning, construc- 
tion management, engineering measures, site design and so on and is still studied in developed countries. Domestic technology level still lags behind that in developed countries.

\subsubsection{Full Process Planning and Design}

Sponge city construction is a systematic project involving urban planning, space layout, vertical design, drainage system planning, hydrology, and meteorology. The governmental hierarchy and department separation cause the difficulties in coordination and organization during sponge city planning. Therefore, it is difficult to guarantee the sponge city effect.

Through the scientific and reasonable systematic design, the idea of sponge city can be implemented in urban development and construction. The investment of traditional grey infrastructure can be reduced and the function and landscape can be promoted. The modeling method, hydro meteorology, geological landscape, drainage system, and underlying surface situation should be analyzed in sponge city planning. According to the experiences obtained in pilot projects, the sponge city construction cost can be reduced by $15 \%$ and the maintenance cost can be reduced by $5 \%$ (Table 1 ).

\subsubsection{LID Project Design and Site Design}

Rainwater source reduction measures mainly refer to LID measure in sponge city planning. The most common forms include bio-retention pond, sinking garden, grass planting ditch, green roof, rain garden, infiltration pond, etc. Technical engineers believe that the plant's adsorption effect on nitrogen and

Table 1. Construction cost and maintenance cost of sponge city.

\begin{tabular}{|c|c|c|c|c|}
\hline \multirow[b]{2}{*}{ Content of Sponge City Construction } & \multicolumn{2}{|c|}{ Investment cost $(10,000 \mathrm{RMB} / \mathrm{y})$} & \multicolumn{2}{|c|}{ Maintenance cost $(10,000 \mathrm{RMB} / \mathrm{y})$} \\
\hline & $\begin{array}{l}\text { Conventional } \\
\text { model }\end{array}$ & $\begin{array}{l}\text { Sponge } \\
\text { city model }\end{array}$ & $\begin{array}{l}\text { Conventional } \\
\text { model }\end{array}$ & $\begin{array}{l}\text { Sponge } \\
\text { city model }\end{array}$ \\
\hline Total & 21,860 & 18,426 & 876 & 831 \\
\hline $\begin{array}{l}\text { 1) Construction and operation maintenance } \\
\text { in residential area }\end{array}$ & 3960 & 5576 & 96 & 144 \\
\hline a) Roof greening & 0 & 200 & 0 & 18 \\
\hline b) Pavement (hard/ permeable) & 1440 & 2160 & 15 & 30 \\
\hline c) Green space (traditional/ecological) & 2160 & 2520 & 65 & 72 \\
\hline d) Green belt (traditional/grass planting ditch) & 360 & 396 & 16 & 18 \\
\hline $\begin{array}{l}\text { 2) Construction and maintenance of rainwater } \\
\text { pipe network and pump station }\end{array}$ & 6500 & 3900 & 360 & 340 \\
\hline 3) Watercourse ecological construction and maintenance & 5100 & 4500 & 270 & 250 \\
\hline $\begin{array}{l}\text { 4) Construction and operational maintenance of } \\
\text { wastewater pipeline and wastewater treatment plant }\end{array}$ & 4500 & 3250 & 141 & 91 \\
\hline $\begin{array}{l}\text { 5) Construction and operational maintenance } \\
\text { of waterlogging prevention facility }\end{array}$ & 1800 & 1200 & 9 & 6 \\
\hline
\end{tabular}


phosphorus in rainwater is one of the sponge's functions, while landscape professionals hold the opposite opinion. In fact, the practice of LID has proved that sponge has filtration and purification functions and that the effect of sponge city varies with soil thickness, type, and quantity. Both biological retention facility and rain garden require a soil replacement according to a certain hierarchy and proportion. German practices also showed that plant root had the functions of loosening soil and supporting soil and provided the living environment for microorganisms, which had the function of purification. Therefore, the keys in ecological green space design include soil layer. Comprehensive functions can be realized through adjusting the proportion of the soil layer and soil thickness as well as improving soil quality. In developed countries, various cities have various choices of plants and soil types. Moreover, the proportion and formation of soil are considered as the core technology in design institutes [12].

Domestic landscape designs consider only the demands of vegetation growth and landscape modeling and fertilizers or pesticides are used to guarantee the growth of vegetation, thus leading to secondary pollution. The key of sponge city construction is to search for the appropriate design method for ecological green garden.

\subsection{Economic Benefit Analysis of Sponge City Construction}

The essence of sponge city is to change the traditional concepts of urban construction and realize the coordinated development of urbanization, resources, and environment [13]. With the development of smart sponge city construction, through networking, cloud computing, data and information technology, a variety of centralized or distributed energy forms, green facilities, and sponge city infrastructure construction are combined together so that sponge city construction and management become efficient and smart [14] [15]. Mature sponge city construction [16] can bring obvious ecological environment and economic benefits.

\subsubsection{Improving Carbon Emission Reduction for Alleviation of Negative Impact of Climate Change}

Collection and utilization of rainwater can be strengthened through sponge city design. The average temperature peak of permeable pavement surface is lower than the average temperature peak of impermeable pavement surface and close to the surface temperature of impermeable pavement surface in shadow. Sponge city construction can alleviate the heat island effect and reduce carbon emission. It is estimated that a $10,000-\mathrm{m}^{2}$ green roof can reduce carbon emission of 20 ton/y and that a 10,000- $\mathrm{m}^{2}$ bio retention facility can reduce carbon emission of 2 ton/y. The total urban area in China is $50,000 \mathrm{~km}^{2}$. According to the state council's requirements, the sponge city area will reach $20 \%$ by 2020 and the reduction of carbon emission will be 760,000 ton/y.

\subsubsection{Remarkable Ecological Environment Benefit of Urban Landscape} Sponge city construction includes various low impact development facilities. Collected rainwater can be used to improve climate, regulate temperature and 
purify air conditions. Moreover, different kinds of plants during construction process can lift the ecological value and the aesthetic quality. Groundwater can be recharged through infiltration, retention, and storage and groundwater quality and water environment can be improved.

\subsubsection{Remarkable Economic Benefit}

First, sponge city construction can reduce the cost of water environment treatment and save pipe network investment. The distributed collection and reuse of nearby rainwater can reduce the overflow pollution in the rainy season, decrease the load of wastewater treatment plants, and cut off the investment cost of municipal infrastructure. Second, sponge city construction can save electricity power. Green roof construction can help to adjust the indoor temperature, reduce the frequency of air conditioning operation, and save the electricity. According to preliminary estimation, $1-\mathrm{m}^{2}$ green roof can save $10 \mathrm{RMB} / \mathrm{y}$ of air conditioning cost. Third, sponge city construction can save water resource. Soil moisture can be increased through sponge city construction. Therefore, the irrigation frequency is reduced and the tap water cost is reduced. Fourth, sponge city construction can reduce water drainage, reduce the pressure of flooding, and save the river channel treatment cost.

\section{Problems Existing in China's Sponge City Construction and Climate Change Adaptation Technology Demands}

\subsection{Technology Gap Analysis}

Compared with foreign developed countries, China's sponge city construction has started lately and fewer experiences are obtained due to the lack of basic information. The technology gap between China and developed countries is obvious. The gap between planning design methods at domestic and oversea is shown in Table 2. The gap between the LID project design and the site design at domestic and oversea is shown in Table 3.

Table 2. Domestic and oversea planning design methods.

\begin{tabular}{ccccc}
\hline Technical Contents & $\begin{array}{c}\text { Domestic } \\
\text { Average Level }\end{array}$ & $\begin{array}{c}\text { Domestic } \\
\text { Advanced Level }\end{array}$ & $\begin{array}{c}\text { International } \\
\text { Advanced Level }\end{array}$ & $\begin{array}{r}\text { Technology Gap between Domestic } \\
\text { Level and International Level }\end{array}$ \\
$\begin{array}{c}\text { Basic information integrity } \\
\text { of meteorological hydrology }\end{array}$ & low & high & high & $\begin{array}{r}\text { Lack of meteorological data, hydrographical } \\
\text { material and difficult to support } \\
\text { the construction of sponge city }\end{array}$ \\
$\begin{array}{c}\text { Basic information integrity } \\
\text { of urban construction status }\end{array}$ & low & medium & high & $\begin{array}{r}\text { Infrastructure (especially underground infrastructure) } \\
\text { is not clear; lack of digital file and } \\
\text { computer model management method } \\
\text { Design calculation method }\end{array}$ \\
$\begin{array}{c}\text { Cross-functionally } \\
\text { cooperation }\end{array}$ & low & medium & high & $\begin{array}{r}\text { Lack of the capacity of mathematical } \\
\text { modeling, analysis, and planning. }\end{array}$ \\
$\begin{array}{c}\text { Full life cycle } \\
\text { economic evaluation }\end{array}$ & low & low & high & $\begin{array}{r}\text { Lack of the coordination among colleague } \\
\text { education, discipline, research and design units, } \\
\text { and urban construction sectors }\end{array}$ \\
\hline
\end{tabular}


Table 3. Domestic and oversea LID project design and site design.

\begin{tabular}{|c|c|c|c|c|}
\hline Technical Contents & $\begin{array}{c}\text { Domestic } \\
\text { Average Level }\end{array}$ & $\begin{array}{c}\text { Domestic } \\
\text { Advanced Level }\end{array}$ & $\begin{array}{c}\text { International } \\
\text { Advanced Level }\end{array}$ & $\begin{array}{l}\text { Technology Gap between Domestic } \\
\text { Level and International Level }\end{array}$ \\
\hline $\begin{array}{l}\text { Technical data of } \\
\text { vertical elevation }\end{array}$ & low & medium & high & Lack of statistical material except individual cases \\
\hline $\begin{array}{l}\text { Coordination between site } \\
\text { design and large scale design }\end{array}$ & low & low & high & $\begin{array}{l}\text { Coordination problem among overall planning, } \\
\text { controlling planning, and engineering design }\end{array}$ \\
\hline $\begin{array}{l}\text { Design method of } \\
\text { sponge garden }\end{array}$ & low & low & high & The basic rules need to be further studied \\
\hline Fine construction level & low & low & high & $\begin{array}{l}\text { Fine construction is hard } \\
\text { To be implemented }\end{array}$ \\
\hline $\begin{array}{l}\text { Connection between above- } \\
\text { and under-ground hydrology, } \\
\text { balance between water } \\
\text { quality and quantity }\end{array}$ & low & low & high & $\begin{array}{l}\text { Gap among different segments; } \\
\text { lack of systematic thinking }\end{array}$ \\
\hline
\end{tabular}

\subsection{Technology Transfer and Application Obstacles Analysis}

The main obstacles in the technology transfer and application of sponge city include the factors in three aspects.

\subsubsection{Strengthening Construction Capacity}

Sponge city construction in developed countries is based on adequate data, complete design scheme, and local meteorological, hydrological, and geological conditions as well as local vegetation. The selections of materials, vegetation, soil composition and structure vary with country. Therefore, foreign experiences cannot be applied directly in China.

Stakeholders include domestic government organizations, scientific research and education institutes, and planning and design institutes.

In order to remove the obstacles, we should enhance the construction capacity, break the segment division, encourage the training of innovative talents, strengthen training and exchange, and improve the planning and design concepts.

\subsubsection{Building the Basic Data Sharing System}

The data sharing system should be built. Otherwise, the foreign model technology or the planning method cannot be applied.

Stakeholders include domestic government organization and scientific research and education institutes.

In order to remove the obstacles, we should promote the reform of the management system, break the interests among various sectors, continuously improve the basis of the data, and promote information sharing and sectoral cooperation.

\subsubsection{Improving Economic Return Mechanism}

The sponge city construction concept has been widely recognized. However, due to the lack of economic drivers and return mechanism, the support from gov- 
ernment investment is not enough and social capitals are not willing to enter the industry of sponge city construction.

Stakeholders include domestic government organization, enterprises, and the masses.

In order to remove the obstacles, we should strengthen the government assessment of sponge city construction, increase evaluation efforts, improve the incentive mechanism, increase the policy guidance and local funding support, and increase publicity efforts to promote pilot projects for the demonstration and education effect.

\section{Case Study on Sponge City Construction in Shenzhen City}

\subsection{Background}

Shenzhen City is located in the south of Guangdong Province. Shenzhen belongs to the sub-tropical monsoon climate with long hours of sunshine, abundant rainfall, and average annual rainfall of $1837 \mathrm{~mm}$ [17]. Its rainfall mostly belongs to short-duration and high-intensity rain and shows uneven spatial and temporal distributions. Moreover, $84.8 \%$ of rainfall occurs in the flood season and rainfall in the eastern region (over $2000 \mathrm{~mm}$ ) is greater than the west (about 1700 $\mathrm{mm}$ ). With the rapid urbanization since the reform and opening-up, the underlying surface in Shenzhen has been changed significantly. Waterlogging is easily formed in some places in low-lying land due to the effect of flood tide.

Climate change has affected Shenzhen significantly. Since 2007 Shenzhen government has realized the traditional measures, such as water diversion and pipe widening, but the problems such as the lack of water, waterlogging, and dirty water are not solved. So the government has adjusted the idea of municipal planning and construction and taken the measures of low impact development for water source control, ecological treatment, and the improvement in the drainage system. The problems of flood and drought go after rain will be solved gradually.

\subsection{Main Methods}

\subsubsection{Planning and Design Control}

To solve the problem of water security, water resource, and water environment in Shenzhen, Guangming New District in Shenzhen started sponge city construction and the construction area was $150 \mathrm{~km}^{2}$, which was equivalent to the area of a large city. Various plans had been formulated, such as the Rainwater Utilization Planning of Guangming New District, the Planning of Low Impact Development in the Starting Region, and the Planning and Design Guidelines of Low Impact Development Projects for Rainwater Utilization. In these plans, LID rainwater utilization was set as rigid requirements of urban planning for the strict control of development and construction. The main contents of the plans are summarized as below:

- The stormwater runoff control rate is no less than $70 \%$ in the newly developed regions with the area of $25 \mathrm{~km}^{2}$. 
- In the newly expanded construction projects with the floor area over 20,000 $\mathrm{m}^{2}$, appropriate rainwater utilization facilities should be constructed.

- Under the 24-h storm condition of the 2-year return period, the total amount of stormwater runoff of the new projects should not be increased after project construction.

- In the renovation and expansion projects, without changing the original municipal storm water pipeline network conditions, the low impact development measures should be adopted to increase the drainage capacity for the storm conditions with the return period of $1-2$ years to the drainage capacity for the storm conditions with the return period of three years.

- The runoff coefficient control requirements of various construction lands are provided as follows. Building land: Living building $\leq 0.4-0.45$, commercial building $\leq 0.45-0.5$, public buildings $\leq 0.4-0.45$, industrial $\leq 0.45-0.5$, logistics and warehousing $\leq 0.5$; road land: road $\leq 0.6$, transport facilities $\leq 0.4$ : green space land: park $\leq 0.1-0.15$, square $\leq 0.2-0.3$.

- The reduction percentage of initial stormwater pollution is not less than $40 \%$.

- To protect rivers, lakes, wetlands, ponds, ditches, and other water ecologically sensitive areas, the planned blue line area is $83.44 \mathrm{~km}^{2}$ and non-construction land (construction prohibition zone and construction restriction zone) is more than $50 \%$ of the whole area.

\subsubsection{Thorough Implementation of the Concept of LID}

In 2007, Guangming New District has launched some LID demonstration projects, such as government-funded public buildings, affordable housing, municipal roads, public green spaces, parks and other water facilities.

Firstly, in public buildings and residential buildings, green roofs, rain gardens, permeable pavement, ecological parking lots, water landscape (storage tanks) and other engineering measures should be adopted, as shown in Figure 3. For example, in public sports center in Guangming New District, green roof area was $23,000 \mathrm{~m}^{2}$ and the area of permeable plaza and ecological parking lot was 13,000 $\mathrm{m}^{2}$. The proportion of the permeable land area in total project area was more than $90 \%$ and the runoff coefficient decreased from $0.7-0.8$ to 0.4 or less. At the same time, the underground reservoir with the capacity of $500 \mathrm{~m}^{3}$ was built to collect purified rainwater from green roof and other facilities, so that water

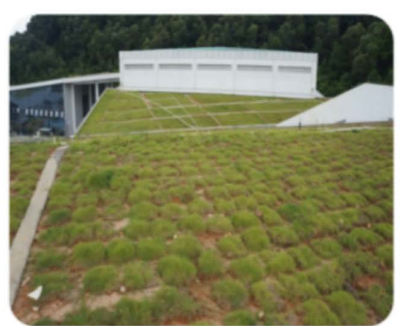

green roof

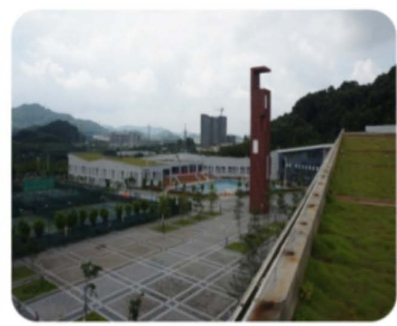

permeable square

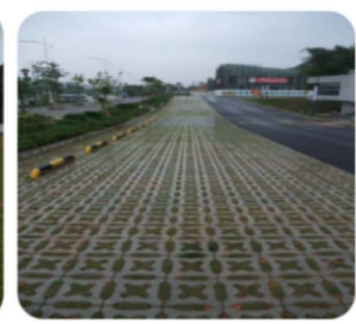

ecological parking lot

Figure 3. LID measures in public buildings and residential area. 
self-supply of green land can be guaranteed during the rainy season. The rainwater utilization amount was over $10,000 \mathrm{~m}^{3}$.

Secondly, in municipal road projects, in the road middle and on both sides of green belts, grooves (10 - $15 \mathrm{~cm}$ below roadway) were constructed and the 20 $40 \mathrm{~cm}$ thick permeable pavement and foundation was constructed on sidewalks and bike paths, as shown in Figure 4. The total length of Park Road, No. 36 Highway and No. 38 Highway in Gateway District was more than $10 \mathrm{~km}$. Concave green land with different structures and filling materials was constructed to collect rainwater within red lines of the road for retention, storage, infiltration, and purification before entering concave green land. Then rainwater exceeding the design capacity entered municipal storm sewers through the overflow port. Water-permeable asphalt roadway was constructed and a variety of warm-mix permeable asphalt, permeable cement, recycled building materials, and other new permeable materials were used in the construction of bike paths. According to the monitoring results, in demonstration roads, no obvious runoff was observed in a light rain; in the rainfall of $4-11 \mathrm{~mm} / \mathrm{h}$, runoff reduction rate and peak reduction rate were respectively up to $95 \%$ and $84 \%$; floor peak was delayed by 12 - 34 min; pollutant reduction was more than $40 \%$. Through the LID measures, the drainage capacity was enhanced and the return period of the municipal road storm sewer was increased from two years up to four years.

Thirdly, in the projects of green parks and plazas, retention ponds, rain gardens, and underground reservoirs were constructed, as shown in Figure 5. In Metro Park with the area of more than 0.5 square kilometers, grass ditches were constructed to transport and purify rainwater and dry stream and rainwater

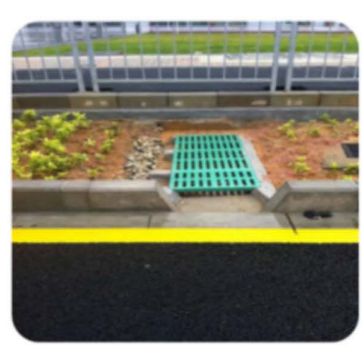

sunken green space

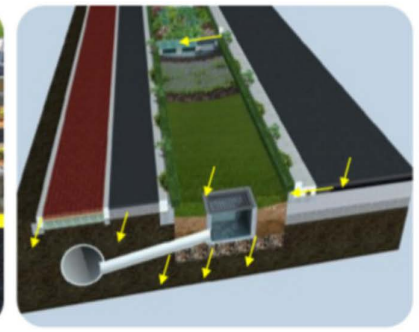

schematic diagram

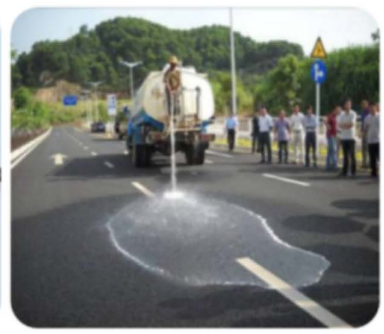

permeable road

Figure 4. LID measures of municipal roads.

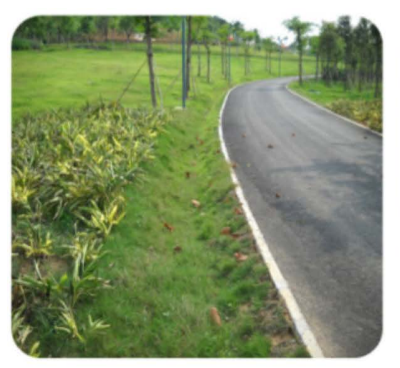

grassed swales

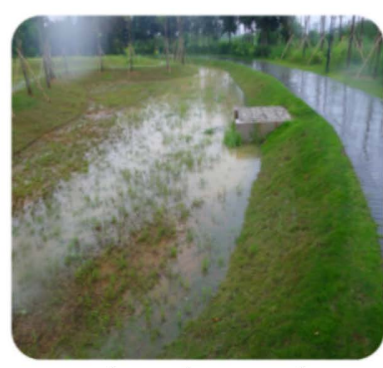

detention pond

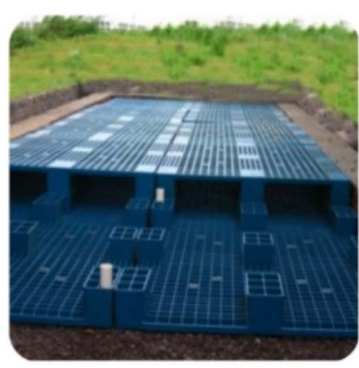

underground reservoir

Figure 5. LID measures in green parks and plazas. 
retention ponds were constructed to reduce the flood peak. At the same time, the underground reservoirs with the capacity of $900 \mathrm{~m}^{3}$ were constructed to collect rain and water pipelines were not constructed any more. The volume of annually collected and reused rainwater was $15,000 \mathrm{~m}^{3}$ and the volume of annually recharged groundwater was $250,000 \mathrm{~m}^{3}$. The drainage load on the downstream municipal storm sewer was decreased.

Fourthly, in the projects of urban water system, artificial wetlands, ecological shoreline, and forest buffers should be constructed to play the role of flood storage and natural purification, thus providing a common space for human beings and water. In Clear Lake City Park, through the investment of RMB 10.18 million, the lake closure pipeline, artificial wetland $\left(12,000 \mathrm{~m}^{2}\right)$, and stabilization pond $\left(16,000 \mathrm{~m}^{2}\right)$ were constructed. In droughty season, sewage was lifted to the municipal wastewater treatment system. In rainy season, initial rainwater and mixed overflow storm sewage passed through eco-ditch and was lifted up to storage tanks (aeration). After purification in artificial wetlands and stabilization ponds, water entered the lake to ensure that the water quality of the lake $\left(300,000 \mathrm{~m}^{3}\right)$ nearly reached the indicators of Type IV surface water. Rain has become an important ecological water source, as shown in Figure 6.

By implementing these sponge city measures, according to estimation results, by 2020 , pre-rain flood and post-rain drought will disappear in Guangming New District and rainstorm waterlogging disaster frequency will be reduced by $50 \%$. According to the stormwater drainage capacity of municipal roads, the return period of the pipeline will be increased from 2 years up to 4 years. Light rain almost leads no rain runoff and the peak load in heavy rain can be decreased. Water self-supply can be realized in all construction projects and the amount of rainwater reuse will be more than $10 \%$ of total urban water supply.

\subsection{Performance}

Sponge city construction in Shenzhen has achieved the following effects. Firstly, the amount of rainwater storage is increased and water conservation capacity, and flood control capacity are enhanced. Secondly, rainwater drainage amount is greatly reduced and pollutants carried by runoff are decreased. Pollutants into the river were reduced and the river water quality was improved. Thirdly, waterlogging drainage capacity is increased and river flood capacity is enhanced.

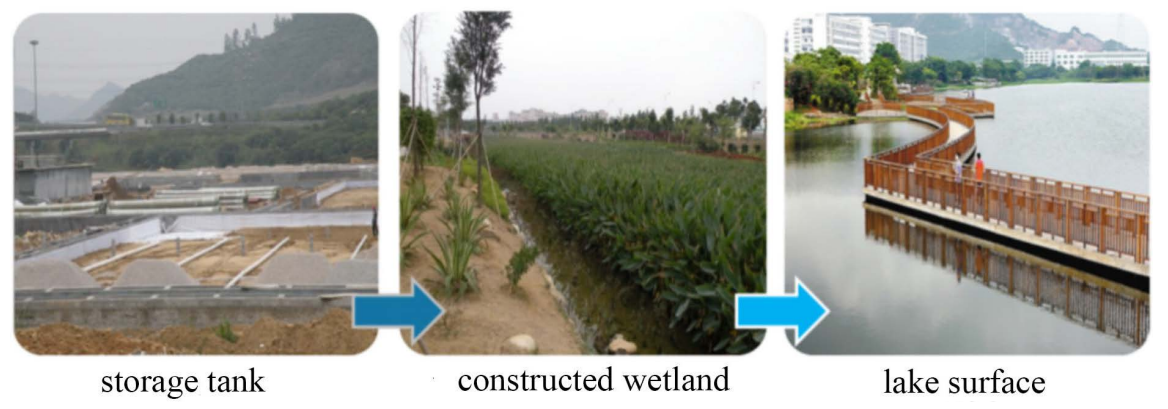

Figure 6. Comprehensive improvement measures of unban river systems. 
The loss of life and property caused by floods was decreased. Fourthly, the pressure on water resources is decreased and water supply capacity is increased.

\section{Conclusions}

Heavy precipitation and storms caused serious waterlogging and other extreme climate change events in modern cities. Sponge city planning and technology are used as the critical approaches for natural rainwater management. Sponge city is one of the best techniques to adapt to climate change. Sponge city is important for maximizing the overall benefits of sustainable development and improving the ability to adapt to climate change.

We analyzed sponge city planning and technology of China and foreign countries. It is necessary to strengthen the technology planning and application ability of sponge city in China, enrich the basic data, complete the design scheme based on local information, break the professional division, encourage innovative compound talents, strengthen training and exchange, and transform planning and design concepts. At the same time, in order to promote information sharing and sectoral coordination, it is necessary to establish and improve the basic information sharing system, break sectoral interests, improve the economic return mechanism, increase the assessment efforts, and enhance publicity efforts for demonstration.

Sponge city construction in Shenzhen started early. Foreign experiences in planning, design, construction, and management have been adopted and achieved remarkable results. However, it should be noted that the basic conditions in the vast majority of domestic cities are not same to those in Shenzhen. Due to the difference in climatic conditions and hydrogeological conditions, experiences obtained in Shenzhen cannot be directly applied in other cities. In a long period, the application of advanced technologies in many domestic cities is facing the process of introduction, digestion, absorption, and re-innovation. At the same time, due to global climate change, water crisis will be more severe in many cities. In order to adapt the construction requirements of new urbanization, sponge city construction based on scientific planning and design methods and sophisticated construction management is the only way for China's urban construction. Sponge city is one of the reliable technology choices for Chinese cities to adapt to climate change.

\section{Acknowledgements}

This study was financially supported by the National Natural Science Foundation of China (Grant No. 41505125) and Special Funds of Public Welfare Projects of Environmental Protection Industry (Grant No. 201509004 and Grant No. 201509040).

\section{References}

[1] NDRC and MOHURD (National Development and Reform Commission of the 
People's Republic of China, Ministry of Housing and Urban-Rural Development of the People's Republic of China) (2016) The Action Plan for Urban Adaptation to Climate Change.

[2] GOSC (General Office of the State Council of the People's Republic of China) (2015) Guiding Opinions of the Advancing the Construction of Sponge Cities.

[3] Che, W., Yan, P. and Zhao, Y. (2014). Development and Analysis of International Updated Stormwater Management Systems. China Water and Wastewater, 18, 45-51.

[4] Li, J.Q. and Wang, W.L. (2015) Construction and Prospect of Urban Rainwater System Based on Multiply Objective. Water and Wastewater, No. 4, 1-3.

[5] Wu, D.J., Zhan, S.Z. and Li, Y.H. (2016) New Trend and Practical Research on the Sponge Cities with Chinese Characteristics. Chins Soft Science, No. 1, 79-97.

[6] MOHURD (Ministry of Housing and Urban-Rural Development of the People's Republic of China) (2014) Sponge Urban Construction Technology Guide, Low Impact Development of Rainwater System Construction (Trial).

[7] Hou, H.F. (2006) Multiple Attribute Decision Making Problem under Incomplete Information and a Class of Multiobjective Decision Making Problems. Xi'an Electronic and Science University, Xi'an.

[8] US EPA (United States Environmental Protection Agency) (2000) Low Impact Development (LID): A Literature Review. Office of Water, Washington DC, EPA-841B-00-005.

[9] Lloyd, S., Wong, T. and Chesterfield, C. (2002) Water Sensitive Urban Design: A Stormwater Management Perspective. CRC for Catchment Hydrology.

[10] Spillett, P.B., Evans, S.G. and Colquhoun, K. (2005) International Perspective on BMPs/SUDS: UK-Sustainable Stormwater Management in the UK. World Water and Environmental Resources Congress, 196.

https://doi.org/10.1061/40792(173)196

[11] Van, M.R., Greenaway, A. and Dixon, J.E. (2006) Low Impact Urban Design and Development: Scope, Founding Principles and Collaborative Learning. 7 th International Conference on Urban Drainage Modeling and the 4th International Conference on Water Sensitive Urban Design; Book of Proceedings, Monash University, Melbourne, 531-538.

[12] Dietz, M.E. (2007) Low Impact Development Practices: A Review of Current Research and Recommendations for Future Directions. Water Air and Soil Pollution. 186, 351-363. https://doi.org/10.1007/s11270-007-9484-z

[13] Chou, B.X. (2015) The Connotation, Approach and Prospect of the Sponge City (LID). Water and Wastewater, No. 3, 1-7.

[14] Li, Y.J., Zhang, C. and Leng, X.Y. (2016) Exploration and Expectation of Smart Sponge City. South to North Water Transfers and Water Science \& Technology, 14, 161-164.

[15] Shi, L. (2011) Smart City Theory and Its Function and Significance of Chinese Urban Development. Forum on Science and Technology in China, No. 5, 97-102.

[16] Xu, J.R., Ten, T.F. and Wang, Y.H. (2016) Analysis on the Comprehensive Dynamic Mechanism of the Sponge City Construction Based on the Case of Henan Province. Science and Technology Management Research, No. 6, 192-198.

[17] Zhang, L., Yu, L. and Ren, X.X. (2015) Construction Strategy of Sponge City Based on Historical Waterlogging Survey in Shenzhen. China Water and Wastewater, 23, 120-124. 